\title{
Purification and Properties of a Phenylcarbamate Herbicide Degrading Enzyme of Pseudomonas alcaligenes Isolated from Soil
}

\author{
J. L. Marty and Joelle Vouges* \\ Groupe d'Etudes et de Recherches Appliquees Pluridisciplinaires, U.A. C.N.R.S. 461, \\ I.U.T. Chemin de la Passio Vella 66025 Perpignan Cedex, France
}

Received June 17, 1987

\begin{abstract}
A phenylcarbamate degrading enzyme was isolated from Pseudomonas alcaligenes. The enzyme was purified to a specific activity of $119 \mathrm{U} / \mathrm{mg}$ by ammonium sulphate precipitation, gel filtration, DEAE and hydroxy-apatite chromatographies. The purified enzyme was found to be homogeneous on SDS polyacrylamide gel electrophoresis. The molecular weight was estimated to 68,000 . The $\mathrm{pH}$ optimum was around 9.5 and the temperature optimum was $28^{\circ} \mathrm{C}$. The $\mathrm{Km}$ for CIPC was $1.19 \times 10^{-5} \mathrm{M} . \mathrm{Hg}^{2+}$, PMSF inhibited the enzyme, but thiol reagents and EDTA had no effect. The enzyme degraded a number of phenylcarbamate herbicides (CIPC, BIPC, IPC and swep) and propanil but did not hydrolyse barban and carbetamide, which are phenylcarbamates, or monuron and linuron, which are phenylureas. The enzyme is probably an amidase.
\end{abstract}

It is generally recognized that pesticides and other xenobiotic compounds represent a considerable threat to the environment, and studies on their metabolism have increased in recent years to determine their fate. The transformation of pesticides in the environment may result from physicochemical reactions as well as from the activity of cellular or extracellular components of the biota (microorganisms, plants and animals). Pesticides are degraded rapidly in soil, and the principal biological pathway is microbial consumption as an energy and carbon source, ${ }^{1)}$ although microorganisms may also degrade pesticides cometabolically ${ }^{2)}$ or by excreting a variety of enzymes which function at a distance from the parent cell. ${ }^{3)}$ Elsewhere, an important aspect of earlier metabolism studies helped to develop a new approach to the detoxification of pesticides using microorganisms or cell-free enzymes from adapted microorganisms. In a recent report ${ }^{4)}$ we described the degradation of various phenylcarbamate herbicides (CIPC, IPC, BIPC and swep) by cometabolic growth of
Pseudomonas alcaligenes cultures isolated from soil. Phenylcarbamates were hydrolyzed to the corresponding aniline, $\mathrm{CO}_{2}$ and alcohol by an inducible intracellular enzyme. ${ }^{4}$ Several workers have isolated enzymes from soil microorganisms which degraded various organophosphate pesticides, ${ }^{5)}$ phenylureas, ${ }^{6}{ }^{6}$ acylanilides, ${ }^{7)}$ phenoxyacetates ${ }^{8)}$ and phenylcarbamates. ${ }^{9)}$ The isolation of the enzyme would permit a better characterization and allow further studies on the enzymatic detoxification of pesticides, which has become an important problem since the expansion of pesticide use.

This paper describes the purification and properties of a phenylcarbamate degrading enzyme.

\section{MATERIALS AND METHODS}

Growth medium. Nutrient growth dehydrated Bio Merieux (Biogelytone, $10 \mathrm{~g}$; meat extract, $6 \mathrm{~g}$ ) was prepared by adding $16 \mathrm{~g}$ to 11 of distilled water. The $\mathrm{pH}$ was 6.9. The medium was sterilized at $120^{\circ} \mathrm{C}$ for $20 \mathrm{~min}$.

Herbicides. The phenylcarbamates used were chlorbufam (BIPC, 1-methyl prop-2-ynyl-3-chlorophenyl-

\footnotetext{
* Present address: ELF Bio-Recherches, Labege Innopole 31328 Castanet Tolosan Cedex, France.
} 
carbamate) obtained from BASF, chlorpropham (CIPC, isopropyl-3-chlorophenylcarbamate) supplied from Schering, propham (IPC, isopropyl- $N$-phenylcarbamate) and swep (methyl 3,4-dichlorophenylcarbamate) purchased from Dow, barban (4 chloro-but-2-ynyl 3 chlorophenyl carbamate) obtained from Spencer Chem. Co., and carbetamide $((R)-(-)-1$-(ethylcarbamoyl)ethyl phenylcarbamate) obtained from Rhone Poulenc. Propanil was purchased from Rohm and Haas, and monuron (3-(4-chloro-phenyl)-1,1-dimethylurea) and linuron (3-(3,4-dichlorophenyl)-1-methoxy-1-methylurea) from Riedel de Haen AG. The purity of all herbicides used was greater than $99 \%$. All other chemicals used were of analytical grade quality.

Microorganism. Pseudomonas alcaligenes has been identified as one soil microorganism which degrades CIPC by cometabolism. ${ }^{4}$

Growth culture. The culture of Pseudomonas alcaligenes was performed in a 21 fermentor (SETRIC, France) with 1.71 of nutrient broth supplemented with $1.7 \mathrm{ml}$ of antifoaming agent (Prolabo 410). Because of the low solubility of CIPC, a stock solution of CIPC was prepared in acetone, from which a specific amount was added to the culture medium $\left(1 \mathrm{ml} \cdot 1^{-1}\right)$. The CIPC concentration was $224 \times 10^{-6} \mathrm{M}$. The rotation speed was $800 \mathrm{rev} \cdot \mathrm{min}^{-1}$ and the oxygen supply was maintained at $501 \cdot \mathrm{h}^{-1}$. Temperature was maintained at $28^{\circ} \mathrm{C}$ by water recycling.

Analytical methods. Herbicides and their metabolites were analyzed by HPLC. The HPLC apparatus consisted of a constametric pump I (LDC) and a spectromonitor III (LDC) with a variable wavelength UV detector monitoring at $236 \mathrm{~nm}$. The column employed was an $\mathrm{NH}_{2}$ Spherisorb model $(5 \mu \times 20 \mathrm{~cm})$. The eluant mixtures used were isooctane-ethanol $(90 / 10)$ for carbetamide; isooctane-ethanol $(96: 4)$ for CIPC, IPC, swep, barban propanil, monuron and linuron; and isooctane-ethanol $(98: 2)$ for BIPC. Herbicides and their respective aniline concentrations were determined from the peaks on chart recorder paper (aniline from IPC and carbetamide; 3chloroaniline from BIPC, CIPC and barban; 4-chloroaniline from monuron, and 3,4-dichloroaniline from swep, propanil and linuron).

Polyacrylamide gel electrophoresis. SDS-polyacrylamide gel electrophoresis was carried out with $12.5 \%$ polyacrylamide gel containing $0.1 \%$ SDS by the technique of Weber et Osborn. ${ }^{10)}$ The gels were stained overnight with Coomassie brilliant blue R 250 .

Determination of molecular weight. The molecular weight of the enzyme was estimated by the method of Andrews, ${ }^{11)}$ using a Sephadex G 150 column.

Protein determination. Protein concentrations were de- termined by the method of Lowry et al., ${ }^{12)}$ using bovine serum albumin to prepare the standard curve. The absorbance at $280 \mathrm{~nm}$ was used for monitoring the protein in the gel filtration and ion exchange column effluents.

Enzyme activity. The enzyme.activity was measured using CIPC as a substrate at a final concentration of $224 \times$ $10^{-6} \mathrm{M}$ in $0.05 \mathrm{M}$ Tris- $\mathrm{HCl}$ buffer at $\mathrm{pH} 8.8$. One unit of enzyme activity is defined as the amount of enzyme producing $1 \mathrm{nmol}$ of 3-chloroaniline per minute at $28^{\circ} \mathrm{C}$ and $\mathrm{pH}$ 8.8. The amount of 3-chloroaniline was determined by HPLC using the method already described. The value for the Michaelis constant, $K m$, was determined from reciprocal plots of the initial reaction rate versus reciprocal plots of the substrate concentration. Universal Britton-Robinson buffer was used to measure the $\mathrm{pH}$ dependence of the activity. The optimum temperature for the reaction was determined by measuring the activity after $30 \mathrm{~min}$ incubation and varying the temperature between 8 and $68^{\circ} \mathrm{C}$.

Purification of the phenylcarbamate degrading enzyme. All steps for enzyme purification were carried out at $4^{\circ} \mathrm{C}$.

Step 1. Preparation of crude extract. Pseudomonas alcaligenes was grown for $24 \mathrm{hr}$ in nutrient broth (BioMerieux France) in the presence of $224 \times 10^{-6} \mathrm{M}$ CIPC. Cells were harvested by centrifugation $(10,000 \times g$ for $10 \mathrm{~min}$ ) and washed three times with cold $0.05 \mathrm{M}$ phosphate buffer at $\mathrm{pH} 7$. The active material was collected by centrifugation and stored at $-20^{\circ} \mathrm{C}$, at which temperature î̀ remained without loss of activity for at least 6 months. Eight grams of cell pellet were suspended in $24 \mathrm{ml}$ of $0.05 \mathrm{M}$ phosphate buffer at $\mathrm{pH} 7$ containing $1 \mathrm{~mm}$ dithiothreitol, and were disrupted with a $375 \mathrm{~W}$ ultrasonic oscillator (Heat System-Ultrasonic). The suspension was treated for a total of 6 min with 2 intervals of 3 min each. The unbroken cells and cellular debris were removed by centrifugation at $36,000 \times g$ for $20 \mathrm{~min}$ (Beckman JA 21). The supernatant fluid was filtered through a $0.22 \mu \mathrm{m}$ membrane (Millipore), the filtrate being the crude extract.

Step 2. Ammonium sulfate fractionation. The enzyme was further purified from the crude extract by the addition of finely ground ammonium sulphate with stirring for $1 \mathrm{hr}$. The major fraction of the active protein was precipitated at a salt concentration of between 40 and $65 \%(\mathrm{w} / \mathrm{v})$. The precipitate was collected by centrifugation at $9,000 \times g$ for $15 \mathrm{~min}$, dissolved in $2.5 \mathrm{ml}$ of $0.05 \mathrm{M}$ Tris-hydrochloride buffer at $\mathrm{pH} 8.8$, and desalted on a Sephadex G25 column (Pharmacia PD 10).

Step 3. Gel filtration. The desalted enzyme was applied to a column $(2.6$ by $55 \mathrm{~cm})$ packed with Sephadex G150 and equilibrated in $0.05 \mathrm{~m}$ Tris-hydrochloride buffer at $\dot{\mathrm{p}} \mathrm{H}$ 8.8. The column was run at $10 \mathrm{ml} \cdot \mathrm{h}^{-1}$. Proteins were eluted in fractions $30 \sim 110$, whereas the enzyme was confined to fractions $50 \sim 70$. The fraction with high specific activity were then pooled $(32 \mathrm{ml})$.

Step 4. Ion-exchange chromatography. The enzyme 
was further purified by chromatography on DEAETrisacryl (I. B. F. France). The resin was equilibrated with $0.05 \mathrm{~m}$ Tris-hydrochloride buffer at $\mathrm{pH} 8.8$ and packed into a column $(1.14 \times 7 \mathrm{~cm})$. The $32 \mathrm{ml}$ sample from the previous gel filtration was then applied and the column was washed with $0.05 \mathrm{~m}$ Tris-hydrochloride buffer at $\mathrm{pH}$ 8.8. The enzyme was eluted at a flow rate of $5 \mathrm{ml} \cdot \mathrm{h}^{-1}$ with $0.05 \mathrm{M}$ Tris-hydrochloride buffer at $\mathrm{pH} 8.8$, using a linear gradient from $0.10 \mathrm{M}$ to $0.15 \mathrm{M} \mathrm{NaCl}$. The fractions containing enzyme activity were pooled and desalted on a Sephadex G25 column (Pharmacia PD 10).

Step 5. Adsorption chromatography. The pooled fractions from 4 were applied to a column $(2 \times 12 \mathrm{~cm})$ packed with hydroxy-apatite Ultrogel (I. B. F. France) and equilibrated in $1 \mathrm{~mm}$ phosphate buffer at $\mathrm{pH}$ 6.8. The column was washed with $1 \mathrm{~mm}$ phosphate buffer at $\mathrm{pH} 6.8$ containing $0.1 \mathrm{M} \mathrm{NaCl}$, and then eluted stepwise at a flow rate of $10 \mathrm{ml} \cdot \mathrm{h}^{-1}$ with increasing concentrations of phosphate $(5 \mathrm{~mm}, 50 \mathrm{~mm}$ and $500 \mathrm{~mm})$. The fractions containing enzyme activity were pooled and concentrated by ultrafiltration with a PM 10 membrane (Amicon).

\section{RESULTS}

\section{Enzyme purification}

The phenyl carbamate degrading enzyme was purified from a cell extract of $P$. alcaligenes by ammonium sulphate precipitation, gel filtration on Sephadex G 150, DEAE trisacryl chromatography and hydroxy-apatite Ultrogel chromatography. The data on the purification are summarized in Table I. The enzyme was purified 360 fold to a specific activity of 119 units/mg protein from the crude extract with a yield of $17 \%$. The purified enzyme gave a single band in SDS polyacrylamide gel electrophoresis (result not shown). This indicated that the purified sample was electrophoretically homogeneous under the dissociating conditions.

\section{Molecular weight}

The molecular weight of the purified enzyme was estimated to be approximately 68,000 by chromatography on a calibrated column of Sephadex G 150 (Fig. 1). The value was confirmed by SDS-polyacrylamide gel electrophoresis (results not shown).

\section{Properties of the enzyme}

Since the level of purified enzyme was very low and the protein proved to be labile during preparation, only partially purified preparations, usually those from steps 3 and 4, were used for enzyme characterization.

\section{pH optimum}

The optimal $\mathrm{pH}$ of the phenylcarbamate degrading enzyme was found to be in the range $9 \sim 9.5$ (Fig. 2). All assays were carried out using Britton-Robinson buffer. The enzyme was active over a wide $\mathrm{pH}$ range, nearly identical results were obtained with $0.05 \mathrm{M}$ Trishydrochloride buffer at $\mathrm{pH} 8.8$ and with $0.05 \mathrm{M}$ phosphate buffer at $\mathrm{pH} 7$.

\section{Temperature}

The temperature dependence of the activity of the phenylcarbamate degrading enzyme was studied in the range from 8 to $68^{\circ} \mathrm{C}$. The reaction mixture was equilibrated at the test

Table I. Summary of the Purification of a Phenylcarbamate Degrading ENZYME FROM Pseudomonas alcaligenes

Details from each purification step are described in Materials AND Methods.

\begin{tabular}{lccccc}
\hline & $\begin{array}{c}\text { Volume } \\
(\mathrm{ml})\end{array}$ & $\begin{array}{c}\text { Total } \\
\text { protein } \\
(\mathrm{mg})\end{array}$ & $\begin{array}{c}\text { Total } \\
\text { activity } \\
\text { (units) }\end{array}$ & $\begin{array}{c}\text { Specific } \\
\text { activity } \\
\text { (units/mg) }\end{array}$ & $\begin{array}{c}\text { Activity } \\
\text { yield } \\
(\%)\end{array}$ \\
\hline $\begin{array}{l}\text { Cell extract } \\
\text { Ammonium sulphate fractionation }(40 \sim 65 \%),\end{array}$ & 20 & 260 & 86.9 & 0.33 & 100 \\
$\quad$ saturation and desalting & 3.5 & 85.6 & 62.5 & 0.73 & 72 \\
$\begin{array}{l}\text { Sephadex G 150 chromatography } \\
\text { DEAE Trisacryl chromatography }\end{array}$ & 32 & 16.04 & 37.5 & 2.34 & 43 \\
$\begin{array}{l}\text { HA Ultrogel chromatography } \\
\text { \& concentration }\end{array}$ & 3.6 & 1.69 & 23.7 & 14.04 & 27 \\
\hline
\end{tabular}




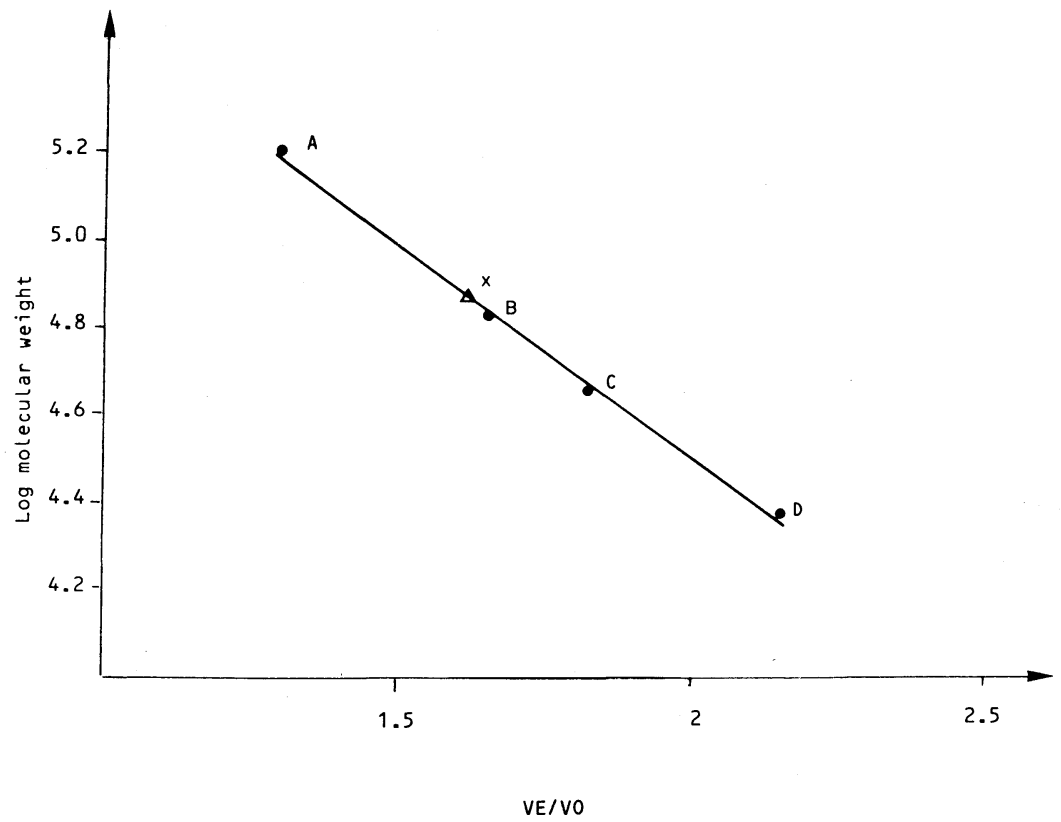

FIG. 1. Estimation of the Molecular Weight of Phenylcarbamate Degrading Enzyme by Sephadex G 150 Gel Filtration.

The column $(2.6 \times 73 \mathrm{~cm})$ was equilibrated with $0.05 \mathrm{M}$ Tris- $\mathrm{HCl}$ buffer at $\mathrm{pH} 8.8$. A, aldolase $(158,000) ; \mathrm{X}$, phenylcarbamate degrading enzyme; B, serumalbumin $(66,000)$; C, ovalbumin $(45,000)$; D, chymotrypsinogen $(25,000)$.

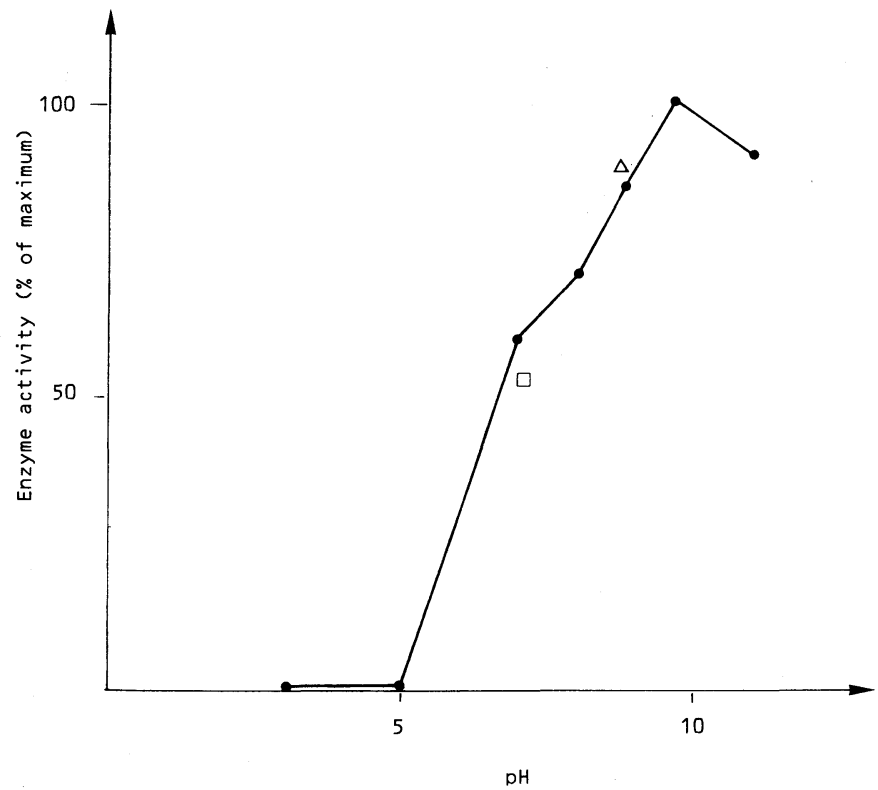

FIG. 2. pH Dependence of the Enzyme Activity.

The activity was measured at $28^{\circ} \mathrm{C}$ and at different pHs by using Britton-Robinson buffer ( $), 0.05 \mathrm{M}$ phosphate buffer at $\mathrm{pH} 7(\square)$, and 0.05 Tris- $\mathrm{HCl}$ buffer at $\mathrm{pH} 8.8(\triangle)$ with CIPC as the substrate to a final concentration of $224 \times 10^{-6} \mathrm{M}$. The enzyme activity is expressed in terms of the percentage of the control (maximum value). 


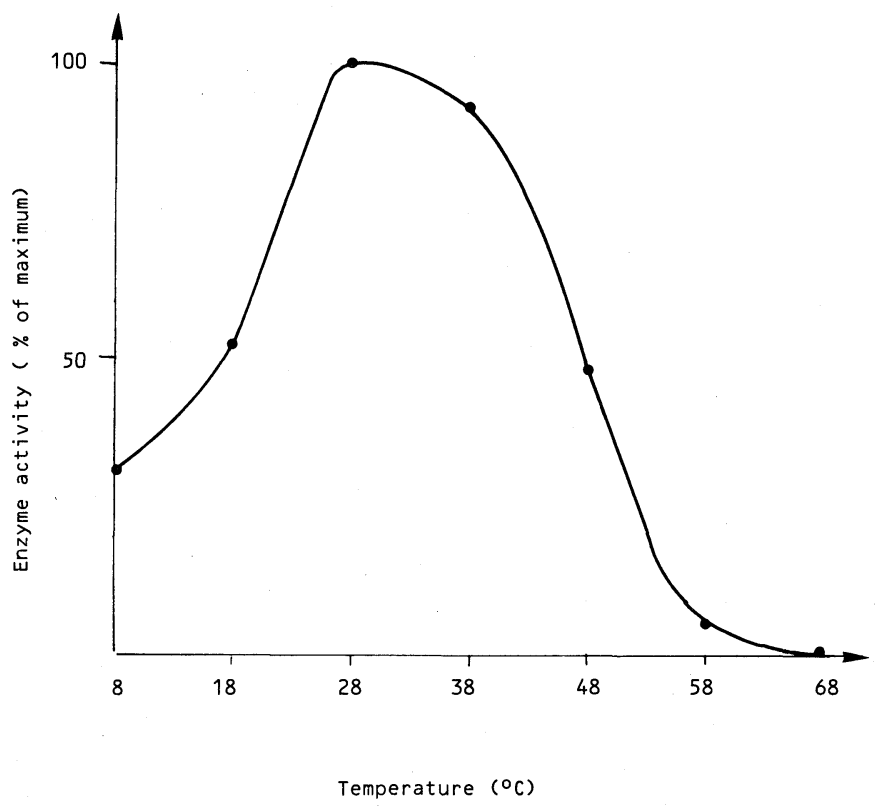

FIG. 3. Optimal Temperature for Enzyme Activity.

The enzyme solutions were incubated with CIPC as a substrate to a final concentration of $224 \times 10^{-6} \mathrm{M}$ for $30 \mathrm{~min}$ at the indicated temperatures. The enzyme activity is expressed in terms of the percentage of the control (maximum value).

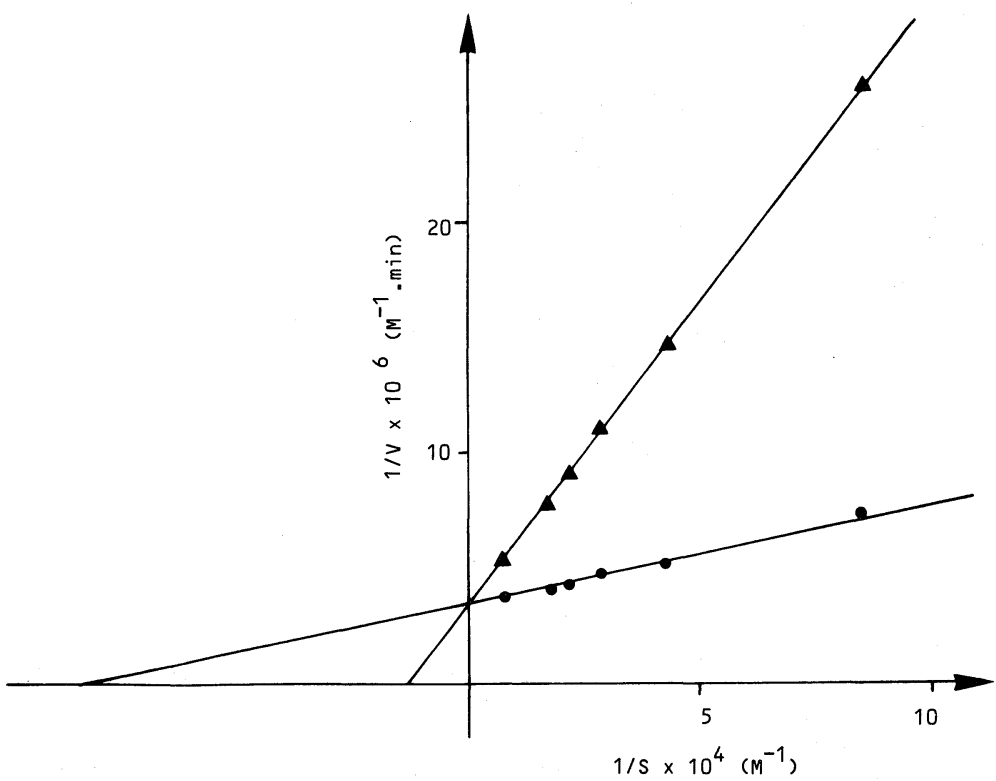

FIG. 4. Lineweaver-Burk Plots for the Hydrolysis of CIPC by Phenylcarbamate Hydrolyzing Enzyme.

The enzyme activity towards the CIPC substrate at various concentrations was measured under the following conditions: buffer, Tris- $\mathrm{HCl}\left(\mathrm{pH} 8.8\right.$ at $\left.28^{\circ} \mathrm{C}\right)$; barban, absence $(\boldsymbol{O})$ or presence $(\mathbf{\Delta})$ at $1.17 \times 10^{-5} \mathrm{M}$; reaction time, $30 \mathrm{~min}$. 
temperature for $10 \mathrm{~min}$ before the addition of a substrate (CIPC) to start the reaction. The reaction rates were compared, the optimum temperature being found to be around $28^{\circ} \mathrm{C}$ (Fig. 3). The enzyme was completely stable at temperatures below $48^{\circ} \mathrm{C}$, retained about $30 \%$ of its original activity on heating to $58^{\circ} \mathrm{C}$ and was completely inactivated by heating to $68^{\circ} \mathrm{C}$ under the conditions used.

\section{Inhibition studies}

Various chemicals, including metal ions, metal-chelating agents and group specific reagents, were tested for inhibition of the phenylcarbamate degrading enzyme. These chemicals were added at the concentrations indicated in Table II for $20 \mathrm{~min}$ at $28^{\circ} \mathrm{C}$, and then the enzyme reaction was carried out for $30 \mathrm{~min}$ with CIPC as a substrate. The enzyme activity was completely inhibited by $\mathrm{Hg}^{2+}$ and PMSF, and to a lesser degiee by $\mathrm{Cd}^{2+}, \mathrm{Cu}^{2+}, \mathrm{Zn}^{2+}$ and $1 \sim 10$ phenanthroline. Inhibition or activation by thiol reagents and EDTA was not significant and the enzyme activity was not affected by the following chemicals: $\mathrm{CaCl}_{2}$, $\mathrm{CoCl}_{2}, \mathrm{FeCl}_{2}, \mathrm{MgCl}_{2}$ and $\mathrm{MnCl}_{2}$.

\section{Michaelis constant}

The effect of CIPC concentration on the enzyme activity in a $\mathrm{pH} 8.8$ buffer solution was studied at $28^{\circ} \mathrm{C}$. The $K m$ value calculated from Lineweaver-Burk plots was 1.19 $\times 10^{-5}$ M (Fig. 4).

\section{Kinetics of inhibition by barban}

Figure 4 illustrates the $1 / V \sim 1 / S$ plots in the absence and presence of $1.17 \times 10^{-5} \mathrm{M}$ barban, CIPC being used as a substrate. The results indicate that the inhibition by barban was of the competitive type. No inhibition was obtained using carbetamide as the inhibitor and the inhibitor constant $(K i)$ value was 1.88 $\times 10^{-6} \mathrm{M}$.

\section{Substrate specificity.}

Phenylcarbamate herbicides and other pesticides (Table III) were tested for substrate specificity, enzyme activity being measured by
TABle II. EFFECtS OF METAL IONS AND Group Specific Reagents on the Activity of the Phenylcarbamate DEGRADING ENZYME

Partially purified enzyme was incubated with various metal ions and reagents at the indicated concentration for $20 \mathrm{~min}$ at $28^{\circ} \mathrm{C}$, and the enzyme reaction was carried out for $30 \mathrm{~min}$ with a CIPC concentration of $224 \times 10^{-6} \mathrm{M}$.

\begin{tabular}{ccc}
\hline $\begin{array}{c}\text { Metal ions } \\
\text { and reagents }\end{array}$ & $\begin{array}{c}\text { Concentration } \\
(\mathrm{mM})\end{array}$ & $\begin{array}{c}\text { Relative } \\
\text { activity } \\
(\%)\end{array}$ \\
\hline Control & 0 & 100 \\
$\mathrm{CaCl}_{2}$ & 5 & 100 \\
$\mathrm{CdCl}_{2}$ & 5 & 78 \\
$\mathrm{CoCl}_{2}$ & 5 & 100 \\
$\mathrm{CuCl}_{2}$ & 5 & 56 \\
$\mathrm{FeCl}_{2}$ & 5 & 100 \\
$\mathrm{HgCl}_{2}$ & 5 & 0 \\
$\mathrm{MgCl}_{2}$ & 5 & 100 \\
$\mathrm{MnCl}_{2}$ & 5 & 100 \\
$\mathrm{ZnCl}_{2}$ & 5 & 74 \\
EDTA $_{1}$ & 2 & 80 \\
$10 \mathrm{Phenanthroline}^{2}$ & 2 & 40 \\
$\mathrm{PMSF}^{a}$ & 1 & 0 \\
$\mathrm{PCMS}^{a}$ & 1 & 83 \\
$\mathrm{NEM}^{a}$ & 1 & 104 \\
Mercaptoethanol & 1 & 103 \\
Dithiothreitol & 1 & 114 \\
\hline
\end{tabular}

a PMSF, phenyl methyl sulphonyl fluoride; PCMS, $p$ chloromercuriphenyl sulphonic acid; NEM, $N$-ethyl maleimide.

\section{TABle III. Substrate Specificity OF THE ENZYME}

The enzyme was incubated with $224 \times 10^{-6} \mathrm{M}$ of various substrates as indicated (barban at $46.8 \times 10^{-6} \mathrm{M}$ because it is slighty soluble). After incubation, the liberated anilines were measured by HPLC, as described in Materials AND Methods. The activity is expressed relative to that observed for CIPC.

\begin{tabular}{lc}
\hline Substrate & $\begin{array}{c}\text { Relative } \\
\text { activity } \\
(\%)\end{array}$ \\
\hline CIPC & 100 \\
BIPC & 35 \\
IPC & 126 \\
Swep & 24 \\
Barban & 0 \\
Carbetamide & 0 \\
Propanil & 88 \\
Monuron & 0 \\
Linuron & 0 \\
\hline
\end{tabular}


the release of anilines or the disappearance of the pesticides. Propanil and all phenylcarbamate herbicides except barban were hydrolyzed, while carbetamide, monuron and linuron were not attacked.

\section{DISCUSSION}

The phenylcarbamate degrading enzyme was purified by ammonium sulphate precipitation, and by a combination of gel filtration, DEAE and hydroxy-apatite chromatographies. The purified preparation was homogeneous on SDS polyacrylamide gels. A comparison of the Pseudomonas alcaligenes enzyme with other aryl or acyl amidases described in the literature reveals various common properties. The molecular weight of the enzyme was estimated to be 68,000 by gel filtration, which was quite close to the value determined for the acylamidase of Bacillus sphaericus $^{6)}$ and for the aryl acylamidase of Pseudomonas aeruginosa ${ }^{13)}$ and Sarcina lutea ${ }^{14)}$ The enzyme was active over a wide $\mathrm{pH}$ range around 9.5, this being similar to the enzyme produced by Pseudomonas striata, which hydrolyzed CIPC ${ }^{9)}$ and other amidases from various sources. ${ }^{6,14)}$ The maximum activity was found near $28^{\circ} \mathrm{C}$, but the enzyme was relatively labile and inactived after $10 \mathrm{~min}$ at $68^{\circ} \mathrm{C}$. The same result was obtained by other workers. ${ }^{6,7)}$ The final specific activity of $119 \mathrm{nmol} \cdot \mathrm{mn}^{-1} \cdot \mathrm{mg}^{-1}$ was low but this level was similar to that of purified related enzymes. ${ }^{6,7)}$ The enzyme was inhibited completely by $\mathrm{Hg}^{2+}$ and partially by $\mathrm{Cu}^{2+}, \mathrm{Cd}^{2+}$ and $\mathrm{Zn}^{2+}$. Similar properties have been described by other workers for aryl acyl amidase. ${ }^{6,9,15)}$ The enzyme was not sensitive to sulfhydryl reagents, suggesting that no sulfhydryl group was present in the active site of the enzyme, and was strongly sensitive to PMSF, which suggests that serine may be involved in this site.

The enzyme was incapable of attacking barban, but hydrolyzed various other phenylcarbamates (CIPC, IPC, BIPC and swep), the structures of these herbicides (Table IV) being
Table IV. Phenylcarbamate Herbicides

\begin{tabular}{|c|c|c|c|}
\hline & $\mathrm{X}$ & $\mathrm{Y}$ & $\mathrm{R}$ \\
\hline IPC & $\mathrm{H}$ & $\mathrm{H}$ & $-\mathrm{CH}_{-}^{-} \stackrel{\mathrm{CH}_{3}}{\mathrm{CH}_{3}}$ \\
\hline CIPC & $\mathrm{Cl}$ & $\mathrm{H}$ & $-\mathrm{CH}=\stackrel{\mathrm{CH}_{3}}{\mathrm{CH}_{3}}$ \\
\hline BIPC & $\mathrm{Cl}$ & $\mathrm{H}$ & $-\mathrm{CH}\left(\mathrm{CH}_{3}\right)-\mathrm{C} \equiv \mathrm{CH}$ \\
\hline Barban & $\mathrm{Cl}$ & $\mathrm{H}$ & $-\mathrm{CH}_{2}-\mathrm{C} \equiv \mathrm{C}-\mathrm{CH}_{2} \mathrm{Cl}$ \\
\hline Swep & $\mathrm{Cl}$ & $\mathrm{Cl}$ & $-\mathrm{CH}_{3}$ \\
\hline Carbetamide & $\mathrm{H}$ & $\mathrm{H}$ & $\begin{array}{l}-\mathrm{CH}-\mathrm{CONH}-\mathrm{CH}_{2}-\mathrm{CH}_{3} \\
\mathrm{CH}_{3}\end{array}$ \\
\hline
\end{tabular}

very similar. The mode of inhibition by barban of CIPC degradation proved to be competitive, whereas carbetamide was not an inhibitor. Further study is required to determine why barban and carbetamide were not hydrolyzed.

The enzyme responsible for hydrolyzing the phenylcarbamates could rise to anilines by two closely related processes. Enzymatic attack at the ester or amide linkage could give anilines, $\mathrm{CO}_{2}$ and alcohol, because the carbamic acid was unstable. The various isolated bacterial enzymes have very different specificities: some are capable of hydrolyzing phenylcarbamates, acylanilides and phenylureas, ${ }^{6}$ ) others only phenylcarbamates and acylanilides ${ }^{9)}$, while others degrade only acylanilides. ${ }^{7)}$ Preliminary results show that the enzyme degraded Lalanine paranitroanilide and had no action on 4-methyl umbelliferyl acetate, which are substrates for amidases and esterases. Furthermore, the enzyme degraded propanil which has an amide function. Thus, it appears that the enzyme was an amidase.

\section{REFERENCES}

1) J. S. Karns, J. J. Kilbane, S. Duttagupta and A. M. Chakrabarty, Appl. Environ. Microbiol., 46, 1176 (1983).

2) A. Krause, W. G. Hancock, R. D. Minard, A. J. Freyer, R. C. Honeycutt, H. M. Le Baron, D. L. Paulson, S. Y. Liu and J. M. Bollag, J. Agric. Food. 
Chem., 33, 584 (1985).

3) J. M. Bollag, "Microbial Transformations of Bioreactive Compounds," ed. by J. P. Rasazza, CRC Press, Baton Rouge, 1982, pp. $125 \sim 168$.

4) J. L. Marty, T. Khafif, D. Vega and J. Bastide, Soil. Biology Biochemistry, 18, 6, 649 (1986).

5) D. M. Munnecke, Appl. Environ. Microbiol., 32, 7 (1976).

6) G. Engelhardt, G. Wallnofer and R. Plapp, Appl. Microbiol., 26, 709 (1973).

7) R. P. Lanzilotta and D. P. Pramer, Appl. Microbiol., 19, 307 (1970).

8) J. M. Tiedje and M. Alexander, J. Agric. Food.
Chem., 17, 809 (1969).

9) P. C. Kearney, J. Agric. Food Chem., 13, 561 (1965).

10) K. Weber and M. Osborn, J. Biol. Chem., 244, 4406 (1969).

11) P. Andrews, Biochem. J., 96, 596 (1965).

12) O. H. Lowry, N. J. Rosebrough, A. L. Farr and R. J. Randall, J. Biol. Chem., 193, 265 (1951).

13) P. S. Riley and F. J. Behal, J. Bacteriol., 108, 809 (1971)

14) F. J. Behal and R. T. Carter, Can. J. Microbiol., 17, 39 (1971).

15) K. Tazaki and N. Ishikama, Plant Cell Physiol., 26, 4, 721 (1985). 